\title{
Neutralization of Epstein-Barr Virus by Nonimmune
}

\author{
Human Serum
}

\author{
ROLE OF CROSS-REACTING ANTIBODY TO HERPES SIMPLEX VIRUS
} AND COMPLEMENT

\author{
Glen R. Nemerow, Fred C. Jensen, and Neil R. Cooper, Department of \\ Molecular Immunology, Research Institute of Scripps Clinic, \\ La Jolla, California 92037
}

\begin{abstract}
A B S TRACT These studies were carried out to investigate the mechanism of neutralization of purified Epstein-Barr virus (EBV) by fresh human serum from normal individuals lacking antibody to the EBV viral capsid (VCA) and nuclear antigens (EBNA). Such individuals thus lack serological evidence of immunity to EBV. Although an enzyme-linked immunosorbent assay (ELISA) with highly purified immobilized EBV detected low levels of IgG antibody reactive with EBV in these normal nonimmune sera, this antibody failed to neutralize EBV in the absence of complement. Studies with depleted sera and mixtures of purified complement proteins at physiologic concentrations showed that the IgG antibody and $\mathrm{Cl}, \mathrm{C} 4, \mathrm{C} 2$, and $\mathrm{C} 3$ of the classical pathway were able to fully neutralize EBV. Mixtures of the purified components of the alternative pathway at physiologic concentrations failed to neutralize purified EBV in the presence or absence of the antibody and the alternative pathway did not potentiate classical pathway-mediated neutralization. No evidence for a requirement for C8 was obtained, precluding lysis as the mechanism of neutralization. Since C3 deposition on the viral surface accompanied classical pathway activation, viral neutralization is most likely secondary to the accumulation of complement protein on the viral surface. A coating of protein on the virus could interfere with attachment to, or penetration of potentially susceptible cells.

Experiments were undertaken to determine the specificity of the IgG antibody in the sera of EBV nonimmune individuals which, together with complement, neutralized EBV. Both purified EBV and herpes
\end{abstract}

\footnotetext{
Received for publication 4 February 1982 and in revised form 2 August 1982.
}

simplex I (HSV-1) absorbed the EBV ELISA reactivity and EBV-neutralizing activity of nonimmune sera, whereas another member of the herpesvirus group, cytomegalovirus, was inactive in this regard. HSV-1 was quantitatively more efficient than $\mathrm{EBV}$ in absorbing reactivity, a finding that indicates that the antibody has a higher affinity for HSV-1 than for EBV. Further absorption studies indicated that the cross-reaction occurred in both directions as EBV also absorbed HSV-l reactive antibodies as tested in an HSV1 ELISA. EBV was also less efficient than HSV-1 in absorbing reactivity with $\mathrm{HSV}-1$. A serum lacking detectable antibodies to both EBV and HSV-1 failed to neutralize EBV. These studies cumulatively indicate that fresh serum from EBV nonimmune individuals neutralizes EBV by the combined action of a previously undescribed cross-reacting antibody apparently elicited by HSV-1 and C1, C4, C2, and C3 of the classical complement pathway.

\section{INTRODUCTION}

Epstein-Barr virus $(\mathrm{EBV})^{1}$ infection in man usually occurs early in life and is not generally accompanied by apparent clinical diseases (1). If the initial contact

\footnotetext{
${ }^{1}$ Abbreviations used in this paper: CBL, cord blood leukocytes: $\mathrm{CBL}^{(\mathrm{EBV}+)}$, Epstein-Barr virus transformed cord blood cell line; CMV, cytomegalovirus; EBNA, Epstein-Barr nuclear antigen; EBV, Epstein-Barr virus; ELISA, enzymelinked immunoabsorbent assay; HSV-1, herpes simplex I virus; PAP, purified alternative pathway proteins; PBS, phosphate-buffered saline, pH 7.4; $\mathrm{VBS}^{++}$, veronal-buffered saline containing $1 \mathrm{mM} \mathrm{Mg}^{++}$and $2.5 \mathrm{mM} \mathrm{Ca}^{++}$; VCA, viral capsid antigen; VSV, vesicular stomatitis virus; $\mathrm{Z}$, reciprocal serum dilution giving $63 \%$ hemolysis of antibody sensitized erythrocytes.
} 
with EBV is delayed until adolescence or adulthood, the virus causes infectious mononucleosis in a significant proportion of individuals (2). In most cases this disorder is self-limiting, but it can progress to a fatal lymphoproliferative disease in immune-deficient individuals $(3,4)$. In addition, EBV is an oncogenic agent in certain nonhuman primates (5) and is a prime candidate for a human cancer virus $(6,7)$.

Host defense against EBV includes cellular immune mechanisms that suppress $B$ lymphocytes infected with $\operatorname{EBV}(8,9)$, humoral antibodies that inactivate EBV before infection $(7,10)$, as well as nonspecific humoral factors $(11,12)$ that may also play an important role in limiting the spread of the virus.

Approximately $80-90 \%$ of adult individuals possess these immunologic defense mechanisms indicative of previous EBV infection (13). However, the remaining population lack detectable EBV antibodies and specific cytotoxic T cells. Such individuals have presumably not been exposed to EBV and would be expected to lack immunity to the virus. We were thus surprised to find that fresh serum from one such individual efficiently neutralized purified EBV in vitro (14). The observation that heating $\left(56^{\circ} \mathrm{C}, 30 \mathrm{~min}\right)$, or chelation of metals in the serum with EDTA abrogated the neutralizing activity suggested complement involvement. Subsequent studies have revealed that sera from other individuals lacking antibodies to viral capsid antigens (VCA) and Epstein-Barr nuclear antigens (EBNA) EBV also neutralized the virus. The following study was undertaken to determine the mechanisms involved in EBV inactivation by nonimmune sera.

\section{METHODS}

Isolation and quantitation of EBV, herpes simplex virus1, cytomegalovirus, and vesicular stomatitis virus. The transforming strain of EBV was isolated from supernates of 12-O-tetracanoyl-phorbol-13-acetate stimulated B95-8 marmoset lymphoblastoid cells by sedimentation on dextran T10 gradients as previously described (14). A single modification in the procedure was the initial concentration of the supernatant fluids by Pellicon (Millipore Corp., Bedford, MA) cassette $\left(10^{8} \mathrm{~mol} \mathrm{wt}\right)$ filtration. EBV preparations were devoid of significant cellular contamination as judged by transmission electron microscopy (14). Tritium-labeled EBV was obtained by addition of $\left[{ }^{3} \mathrm{H}\right]$ thymidine to $\mathrm{B} 95-8$ cultures as previously described (14). Herpes simplex virus I (HSV1) was produced in hamster kidney cells (BHK-21) and purified on $15-50 \%$ (wt/wt) Renograffin (E. R. Squibb \& Co., Princeton, NJ) gradients. Cytomegalovirus (CMV), strain AD169, was produced in human embryonic skin fibroblasts. EBV and HSV-1 were quantitated by determination of the DNA content of each virus preparation as follows. Aliquots of virus were disrupted by incubation $\left(37^{\circ} \mathrm{C}, 10 \mathrm{~min}\right)$ in 0.3 $\mathrm{N} \mathrm{NaOH}$ and the released DNA was detected spectrophotometrically at $260 \mathrm{~nm}$. The concentration of DNA was then calculated to determine the number of virus particles using the extinction coefficient of DNA in $\mathrm{NaOH}(\epsilon=37.0)$ and the number of particles determined using a molecular weight of $1.1 \times 10^{8}$ for EBV (15) and HSV-1 (16) DNA. The values obtained by this method correlated well with the viral titers performed by infectivity assays. Vesicular stomatitis virus (VSV) was produced in BHK cells and titered as previously described (17).

Lymphoblastoid and cord blood mononuclear cells. Human fetal umbilical cord blood was collected into sterile tubes containing a final concentration of $20 \mathrm{mM}$ EDTA and the mononuclear cord blood leukocytes (CBL) isolated by sequential sedimentation on 1.09 and $1.077 \rho$ Ficoll-Hypaque gradients as previously described (18). A transformed cell line, designated $\mathrm{CBL}^{(\mathrm{EBV}+)}$, was established by infection of isolated CBL with purified EBV. These cells and B95-8 and Raji lymphoblastoid cell lines were maintained $\left(37^{\circ} \mathrm{C}\right.$, $5 \% \mathrm{CO}_{2}$ ) in RPMI 1640 (Flow Laboratories, Inglewood, CA) containing $10 \%$ fetal calf serum.

Immune and nonimmune reagents. Fluorescein conjugated anti-human IgG, used with the VCA test kit, was obtained from Litton Bionetics (Kensington, MD). Monospecific antibody to human C3, C8, and IgG were produced by immunization of goats with the purified proteins.

Nonimmune sera were obtained from adult individuals lacking detectable antiviral antibodies (VCA $<1: 1$ and EBNA < 1:2) as determined by immunofluorescence (19). Nonimmune serum from a 4-mo-old infant who lacked IgG antibodies to both EBV and HSV-l was kindly provided by Dr. Richard O'Connor (University of California at San Diego, Department of Pediatrics). EBV immune sera were obtained from normal individuals having VCA titers of 1:20$1: 160$. Hyperimmune serum containing normal $\mathrm{C}$ activity was generously provided by Dr. Bonnie Mills (City of Hope Hospital, Duarte, CA) from a patient with nasopharyngeal carcinoma (VCA $1: 5,120$ ). The three types of sera noted above are referred to as normal nonimmune, normal immune, and hyperimmune in this paper. Serum from an agammaglobinemic patient contained $3.8 \mu \mathrm{g} / \mathrm{ml}$ of serum IgG and no detectable IgM or $\operatorname{IgA}(<70 \mu \mathrm{g} / \mathrm{ml})$. This serum had normal complement activity after reconstitution with purified Clq at $70 \mu \mathrm{g} / \mathrm{ml}$. The IgG fractions of these sera were prepared by ammonium sulfate precipitation followed by DEAE-cellulose column chromatography. The purified IgG fractions were sterile filtered and stored at concentrations of $10-35 \mathrm{mg} / \mathrm{ml}$ in phosphate-buffered saline (PBS) at $-70^{\circ} \mathrm{C}$.

Complement $(C)$ components and reagents. Human $\mathrm{Clq}$ (20), Clr (21), Cls (22), C4 (23), C2 (24), C3 (25), and Cl inhibitor (26) were isolated from human serum by published methods. Component $\mathrm{Cl}$ was assembled with purified $\mathrm{Clq}$, $\mathrm{Clr}$, and $\mathrm{Cls}$ at equimolar ratios to achieve a hemolytic titer equivalent to that of serum $\mathrm{Cl}(1 \mathrm{Z}=80,000)$. The purified reassembled classical pathway included Clq $(70 \mu \mathrm{g} / \mathrm{ml}), \mathrm{Clr}$ $(34 \mu \mathrm{g} / \mathrm{ml}), \mathrm{Cls}(3 \mathrm{l} \mu \mathrm{g} / \mathrm{ml}), \mathrm{C} 4(600 \mu \mathrm{g} / \mathrm{ml}), \mathrm{C} 2(25 \mu \mathrm{g} / \mathrm{ml})$, and $\mathrm{C} 3(1.2 \mathrm{mg} / \mathrm{ml})$, which were assembled to achieve the level of serum $\mathrm{C}$ components. The purified alternative proteins (PAP) assembled at serum concentration included Factor $\mathrm{B}(200 \mu \mathrm{g} / \mathrm{ml}), \mathrm{C} 3(1,200 \mu \mathrm{g} / \mathrm{ml})$, factor $\mathrm{D}(2 \mu \mathrm{g} / \mathrm{ml})$, properdin $(20 \mu \mathrm{g} / \mathrm{ml})$, C3bINA (I) $(34 \mu \mathrm{g} / \mathrm{ml})$, and BIH (H) $(470 \mu \mathrm{g} / \mathrm{ml})$ as previously described (27). The PAP proteins were assayed for activity by lysis of rabbit erythrocytes (RaE).

Preparation of IgG and complement component-depleted serum reagents. EBV immune serum was depleted of IgG by passage through a column of monospecific antibody to IgG coupled to CNBr-activated Sepharose 4B (Pharmacia Fine Chemicals, Piscataway, NJ). The classical and alternative pathway levels of the depleted sera following reconstitution of $\mathrm{Ca}^{++}$and $\mathrm{Mg}^{++}$and purified $\mathrm{Clq}(70 \mu \mathrm{g}$ / 
$\mathrm{ml}$ ) as measured by $\mathrm{CH}_{50}$ and $\mathrm{RaE}$ hemolytic assays were normal. Nonimmune serum was depleted of $\mathrm{C} 8$ by passage through a column of monospecific IgG antibody to C8 coupled to $\mathrm{CNBr}$-activated Sepharose $4 \mathrm{~B}$ in the presence of 0.01 $M$ EDTA. After reconstitution of this reagent with purified $\mathrm{C} 8, \mathrm{Clq}$, and metal ions, full hemolytic activity $\left(\mathrm{CH}_{50}\right)$ was restored. Nonimmune serum was depleted of both $\mathrm{Clq}$ and factor D by passage over a Bio-Rex 70 (Bio-Rad Laboratories, Richmond, CA) column in the presence of $2 \mathrm{mM}$ EDTA as previously described (20). The Clq- and D-depleted serum lacked both classical and alternative pathway hemolytic activities that could be selectively restored to normal levels by addition of either purified Clq or factor D. The depleted sera were extensively dialyzed against veronalbuffered saline (VBS) containing $2.5 \mathrm{mM} \mathrm{Ca}^{++}$and $1 \mathrm{mM}$ $\mathrm{Mg}^{++}$ions.

Density gradient ultracentrifugal analysis of EBV interactions with complement. Tritium-labeled EBV was used to study the interactions of complement with the virus. EBV $\left(4 \times 10^{6}\right.$ particles in $\left.40 \mu \mathrm{l}\right)$ was incubated with an equal volume of nonimmune serum or IgG-depleted immune serum for $30 \mathrm{~min}$ at $37^{\circ} \mathrm{C}$. Subsequently, $80 \mu \mathrm{l}$ of monospecific rabbit anti-human C3 (IgG fraction at $5 \mathrm{mg} / \mathrm{ml}$ ) or buffer was added to the samples and incubation continued for 15 min. The samples were then subjected to density gradient ultracentrifugation on 5-30\% continuous dextran T-10 gradients in Tris-NaCl-bacitracin (TNB) buffer. Rate zonal ultracentrifugation was performed in a SW 50.1 rotor at 20,000 $\mathrm{rpm}$ for $45 \mathrm{~min}$ and fractions analyzed for the presence of the ${ }^{3} \mathrm{H}$-labeled DNA. Controls for nonspecific binding of C3 to the virus included EBV incubated with serum chelated with either $10 \mathrm{mM}$ EDTA or $10 \mathrm{mM} \mathrm{Mg}^{++}, 10 \mathrm{mM}$ EGTA before addition of anti-C3.

VCA and EBNA assays. Antibodies to Epstein-Barr VCA (28) and EBNA (19) antigens were detected by indirect immunofluorescence as previously described. The antibody titers directed against these antigens were expressed as the reciprocal of the highest dilution of serum giving a positive staining reaction

Enzyme-linked immunosorbent assay (ELISA) for detection of antibody to EBV and HSV-1. IgG and IgM antibodies to EBV or HSV-1 were detected with an ELISA assay system. Briefly, $10^{6}$ viral particles in $100 \mu \mathrm{l}$ of $0.01 \mathrm{M}$ carbonate buffer, pH 9.6, were added to each of the wells of 96-well polystyrene microtiter plates (Flow Laboratories, Inglewood, CA). The plates were dried by vacuum dessication and then washed once each in PBS-Tween-20 (0.05\%)ovalbumin $(0.5 \%)$ and PBS-Tween for $5 \mathrm{~min}$ at ambient temperature. After decanting the final wash solution, dilutions of sera or of purified IgG in 50- $\mu$ l vol of PBS were then added and the plates gently rocked for $1 \mathrm{~h}$ at room temperature. After removal of the test samples and three washes in PBS-Tween, $50 \mu \mathrm{l}$ of a dilution of glucose-oxidase conjugated goat anti-human IgG or anti-IgM (kindly provided by Roy M. Johnson, Research Institute of Scripps Clinic) were added and the plates incubated for $1 \mathrm{~h}$ at room temperature. The plates were again washed three times with PBS-Tween and developed with $200 \mu$ l of substrate solution containing $10 \%$ glucose in $0.1 \mathrm{M}$ phosphate buffer, $\mathrm{pH} 6.0$, $8 \mu \mathrm{g} / \mathrm{ml}$ peroxidase and $160 \mu \mathrm{g} / \mathrm{ml} 2,2$ azino-di-(3-ethybenzthiazoline sulfonic acid) (Sigma Chemical Co., St. Louis, MO). Reactions were read spectrophotometrically after 60 min at $405 \mathrm{~nm}$ in a Titertek (Flow Laboratories, McLean, VA) ELISA plate reader. Background absorbance was determined by addition of substrate to wells containing all reactants except the antibody conjugate. Background values (usually $<\mathrm{A}_{405}=0.02$ ) were subtracted from the test sample readings. To determine the amount of specific antiviral IgG antibody detected in the ELISA, a standard curve was generated using goat anti-human $\mathrm{FC}(4 \mu \mathrm{g} /$ well) coupled to the ELISA plates. Varying amounts of purified human IgG in $50 \mu \mathrm{l}$ of PBS were added (12.5 to $100 \mathrm{ng} /$ well) and after incubation and washing as described above, $50 \mu \mathrm{l}$ of glucoseoxidase conjugated goat anti-human $\mathrm{F}\left(\mathrm{ab}^{\prime}\right)_{2}$ (kindly provided by Roy Johnson) was added. After a second incubation for $60 \mathrm{~min}$, the reaction was developed with the substrate as described above.

Neutralization and viral infectivity assays. EBV infectivity was assayed by the ability of the virus to stimulate DNA synthesis in CBL as measured by incorporation of $\left[{ }^{3} \mathrm{H}\right]$ thymidine $(29)$. This assay can be used to quantitate the amount of tranforming virus in a given sample since only viable EBV will stimulate DNA synthesis in neonatal B cells (14). Thymidine incorporation was determined $4 \mathrm{~d}$ after infection rather than at $10-14 \mathrm{~d}$ as previously used (14). A linear relationship also prevails between incorporation and purified EBV input $4 \mathrm{~d}$ after infection. Incorporation on day 4 represented specific viral activity and not a nonspecific mitogenic effect as immune, but not nonimmune, human anti-EBV IgG completely abrogated incorporation. Viral neutralization assays by colony formation (14) also correlate with the response at day 4 . Complement proteins and serum reagents were usually sterile filtered before initiating neutralization experiments. Equal volumes of virus $\left(7.5 \times 10^{6}\right.$ particles in $75 \mu \mathrm{l}$ ) and $\mathrm{C}$ proteins (in $\mathrm{VBS}^{++}$buffer) in concentrations equivalent to those present in undiluted normal sera were incubated at $37^{\circ} \mathrm{C}$ for $45 \mathrm{~min}$. Next, $2 \times 10^{5} \mathrm{CBL}$ were added and incubation continued for $60 \mathrm{~min}$ at $37^{\circ} \mathrm{C}$ in a $5 \% \mathrm{CO}_{2}$ humidified incubator. The $\mathrm{CBL}$ were then washed with RPMI media, plated in microtiter plates, and pulsed with $2 \mu \mathrm{Ci}$ of $\left[{ }^{3} \mathrm{H}\right]$ thymidine $4 \mathrm{~d}$ later. Background incorporation of $\left[{ }^{3} \mathrm{H}\right]$ thymidine, was subtracted from the experimental values to obtain specific incorporation. All assays were performed in triplicate or quadruplicate and the results expressed as the average incorporation of $\left[{ }^{3} \mathrm{H}\right]$ thymidine.

Absorption of nonimmune IgG and serum with virus. Purified EBV, HSV-1, CMV, or VSV were used to absorb either serum or purified IgG obtained from individuals nonimmune to EBV. $50 \mu \mathrm{l}$ of $\mathrm{EBV}, \mathrm{CMV}, \mathrm{HSV}-1$, or VSV, in amounts specified in the text, were added to $50 \mu \mathrm{l}$ of whole serum or purified nonimmune IgG $(90 \mu \mathrm{g})$ and the mixtures allowed to incubate overnight at $4^{\circ} \mathrm{C}$. Subsequently, the IgGvirus complexes were removed by airfuge ultracentrifugation (Beckman Instruments, Inc., Palo Alto, CA) and the supernatant analyzed for EBV neutralizing activity in the presence of complement as described above. The supernatant was also analyzed for ELISA reactivity to EBV or HSV1. Controls included nonimmune IgG preincubated with either VSV or PBS.

\section{RESULTS}

Examination of normal nonimmune, normal immune and hyperimmune human sera for the presence of EBV antibody by ELISA assay. As previously noted, a fresh normal nonimmune human serum lacking both VCA and EBNA antibodies to EBV was found to neutralize the virus (14). Because $\sim 10 \%$ of the population lacks these antibodies (13), it was of interest to determine whether sera from other such individuals 
TABLE I

Reactivity of Human Serum with EBV

\begin{tabular}{lcrrr}
\hline \multicolumn{1}{c}{ Serum source } & Neutralization & $\begin{array}{c}\text { ELISA } \\
\text { IgG }\end{array}$ & VCA $\$$ & EBNA $\$$ \\
\hline & $\%$ & $n g / m l$ & titer & titer \\
Agammaglobinemic & 3.0 & 90 & $<1$ & ND \\
Nonimmune 1 & 60.0 & 180 & $<1$ & $<2$ \\
Nonimmune 2 & 53.0 & 210 & $<1$ & $<2$ \\
Nonimmune 3 & 51.0 & 165 & $<1$ & $<2$ \\
Immune 1 & 78.0 & 800 & 160 & 40 \\
Immune 2 & $\mathrm{ND}$ & 940 & 160 & $\mathrm{ND}$ \\
Immune 3 & 87.0 & 960 & 80 & 20 \\
Nasopharyngeal & & & & \\
carcinoma & 97.0 & 1,360 & 5,120 & 640 \\
\hline
\end{tabular}

- Neutralization of EBV by undiluted fresh serum was determined by inhibition of DNA synthesis in CBL.

The amount of specific IgG antibody to EBV was obtained from a standard curve using purified human IgG and anti-human $\mathrm{FC}$ antibody coupled to ELISA wells.

\$ IgG antibodies to EBV viral capsid antigen or EBV nuclear antigen as assayed by indirect immunofluorescence on EBV-infected lymphoblastoid cells. Values expressed as the reciprocal of the highest dilution of serum showing positive staining.

"Serum from a patient with $\sim 3.8 \mu \mathrm{g} / \mathrm{ml}$ of IgG and no detectable IgM or IgA.

ND, not done.

also neutralized the virus, two of which along with the first individual ( 1 in Table $I$ ) are shown in Table $I$. For comparison, the VCA and EBNA titers, neutralizing activity and ELISA reactivity (see below) of three normal immune human sera, an agammaglobinemic serum and the hyperimmune serum are given in Table I. Although not shown, the ability of normal nonimmune human sera to neutralize EBV was abrogated by heating for $30 \mathrm{~min}$ at $56^{\circ} \mathrm{C}$. The heat labile nature of the neutralizing activity of normal nonimmune sera clearly distinguishes these sera from sera obtained from normal immune individuals as such sera fully neutralize EBV after heating (14). To determine whether such nonimmune sera contained low levels of EBV antibody not detectable in the VCA and EBNA tests, or alternatively, antibody to other EBV antigens, an ELISA was developed. In this assay, polystyrene plates coated with purified EBV were reacted with varying dilutions of sera. After washing, bound antibody was detected by reactivity with enzyme conjugated anti-human IgG or anti-human IgM. As seen in Fig. $1 \mathrm{~A}$ and Table I the ELISA detected low levels of IgG antibody reactive with $\mathrm{EBV}$ in nonimmune sera. Normal immune sera (Fig. $1 B$ and Table I) and the nasopharyngeal carcinoma hyperimmune serum (Fig.

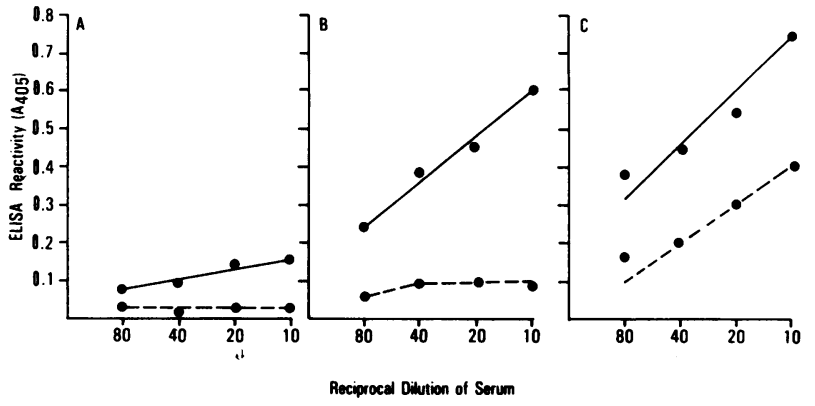

Figure 1 ELISA assay for detection of $\operatorname{IgG}(--0)$ and $\operatorname{IgM}(--\infty)$ antibodies to EBV in the serum of (A) normal nonimmune, (B) normal immune, and (C) nasopharyngeal carcinoma (hyperimmune) sera. The normal nonimmune serum is the nonimmune serum 1 in Table $I$ and the normal immune serum is the immune in Table $I$.

IC and Table I) exhibited higher levels of IgG antibody reactive with EBV in the ELISA assay. Only the hyperimmune serum showed reactivity with the antiIgM antibody (Fig. 1). In order to determine whether the observed IgG reactivity was specific for EBV the normal nonimmune and immune sera were preabsorbed with purified EBV $\left(2 \times 10^{7}\right.$ virions $/ 50 \mu$ l sera $)$ and then tested by the EBV ELISA for IgG antibody. As seen in Fig. 2, this procedure removed all of the detectable EBV-reactive IgG antibody from a normal nonimmune serum and $\sim 70 \%$ of the antibody in the immune serum. Table I also shows that there is no apparent quantitative correlation between the VCA, EBNA, and the ELISA titers. The above studies established the specificity of the EBV ELISA and demon-

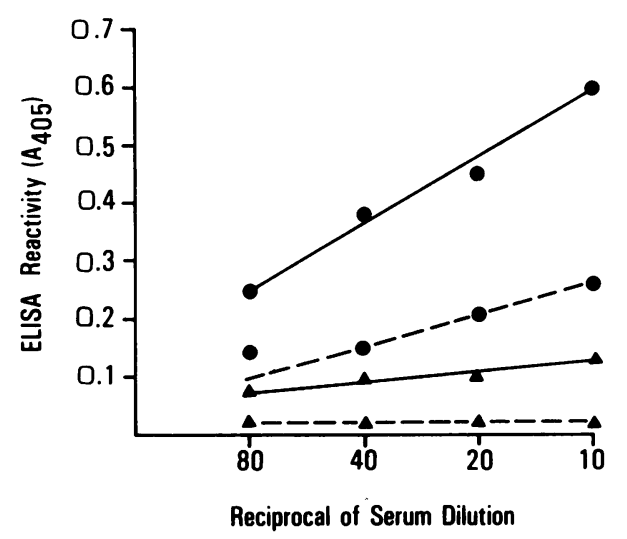

FIGURE 2 Absorption of EBV ELISA reactive IgG antibodies in normal immune and nonimmune serum with purified EBV. Normal immune serum (- - o ) or nonimmune serum $(\Delta-\Delta)$ was preabsorbed with $2 \times 10^{7} \mathrm{EBV}$ virions before being assayed for residual EBV IgG antibodies ( - - $\bullet, \Delta---\Delta$ ) by the ELISA technique. 
strated that normal nonimmune human sera contained low levels of IgG antibody reactive with EBV.

Antibody and complement requirements for EBV neutralization by nonimmune sera. Studies were carried out to determine whether antibody, antibody and complement, or complement alone was required for EBV neutralization by normal nonimmune sera. As expected from the heat labile nature of EBV neutralization by nonimmune sera, physiological concentrations of isolated IgG from such sera did not neutralize EBV (Table II). Nevertheless IgG was required for neutralization as an IgG-depleted immune serum (not shown) and an agammaglobinemic serum (Table I), both containing adequate $\mathrm{C}$ levels, failed to neutralize EBV. Reconstitution of these sera with purified immune IgG fully restored this activity. Further studies with $\mathrm{C}$ component-depleted nonimmune serum were carried out to determine the complement pathway used for EBV neutralization. Nonimmune serum depleted of both Clq and factor D failed to significantly neutralize EBV (Table II). Purified Clq significantly restored neutralizing activity to the serum. Factor D neither restored neutralizing activity to the depleted serum nor potentiated the neutralization observed with restoration with Clq. The above studies indicated requirements for both IgG and the classical pathway for EBV neutralization by nonimmune human serum.

The complement proteins required for neutralization were examined in the following studies. Purified

TABLE II

Neutralization of EBV by Clq and Factor D-depleted Nonimmune Human Serum

\begin{tabular}{lcc}
\hline \multicolumn{1}{c}{ Sample } & $\begin{array}{c}\text { Specific }\left[{ }^{3} \mathrm{H}\right] \mathrm{TdR} \\
\text { incorporation }\end{array}$ & $\begin{array}{c}\text { Neutral- } \\
\text { ization }\end{array}$ \\
\hline & $c p m$ & $\%$ \\
EBV control & 44,000 & - \\
EBV + nonimmune IgC & 41,500 & 5 \\
EBV control & 30,700 & - \\
EBV + nonimmune serum & 5,600 & 82 \\
EBV + Clq and factor D-depleted & 25,000 & 19 \\
$\quad$ nonimmune serum & & \\
EBV + Clq and factor D-depleted & & \\
$\quad$ nonimmune serum + purified & 12,100 & 61 \\
Clq & & \\
EBV + Clq and factor D-depleted & & \\
$\quad$ nonimmune serum + purified & 28,400 & \\
factor D & & 67 \\
EBV + Clq and factor D-depleted & & 14 \\
nonimmune serum + purified & 11,200 & 10 \\
Clq + factor D & 26,700 & \\
EBV + Clq & 27,800 & \\
EBV + factor D & & \\
\hline
\end{tabular}

TABIE: III

Neutralization of EBV by Nonimmune $\operatorname{IgG}$ and Purified C Components

\begin{tabular}{|c|c|c|}
\hline Sample & $\begin{array}{l}\text { Specific }\left[{ }^{3} \mathrm{H}\right] \mathrm{TdR} \\
\text { incorporation }\end{array}$ & $\begin{array}{l}\text { Neutral- } \\
\text { ization }\end{array}$ \\
\hline & $c p m$ & $\%$ \\
\hline EBV control & 20,000 & - \\
\hline $\mathrm{EBV}+$ nonimmune serum & 3,100 & 85 \\
\hline $\mathrm{EBV}+$ nonimmune $\mathrm{IgG}$ & 21,400 & -2 \\
\hline $\mathrm{EBV}+\mathrm{Cl}, \mathrm{C} 4, \mathrm{C} 2, \mathrm{C} 3$ & 19,300 & 4 \\
\hline $\begin{array}{l}\mathrm{EBV}+\text { nonimmune } \operatorname{IgC}+\mathrm{Cl} \\
\mathrm{EBV}+\text { nonimmune } \operatorname{IgG}\end{array}$ & 18,200 & 9 \\
\hline$+\mathrm{Cl}, \mathrm{C} 4$ & 18,600 & 7 \\
\hline $\begin{array}{l}\mathrm{EBV}+\text { nonimmune IgG } \\
\quad+\mathrm{C} 1, \mathrm{C} 4, \mathrm{C} 2\end{array}$ & 19,600 & 2 \\
\hline $\begin{array}{l}\mathrm{EBV}+\text { nonimmune IgG } \\
\quad+\mathrm{C} 1, \mathrm{C} 4, \mathrm{C} 2, \mathrm{C} 3\end{array}$ & 6,300 & 69 \\
\hline $\begin{array}{l}\text { EBV + nonimmune IgG } \\
\quad+\text { PAP }\end{array}$ & 22,800 & -7 \\
\hline $\mathrm{EBV}+\mathrm{PAP}$ & 20,300 & -2 \\
\hline
\end{tabular}

EBV was reacted with varying combinations of purified nonimmune human $\mathrm{IgG}, \mathrm{Cl}, \mathrm{C} 4, \mathrm{C} 2$, and $\mathrm{C} 3$ (Table III). No neutralization was observed at the Cl, $\mathrm{Cl}$ and $\mathrm{C} 4$ or $\mathrm{Cl}, \mathrm{C} 4$, and $\mathrm{C} 2$ stage of the reaction sequence; only mixtures containing IgG together with $\mathrm{Cl}, \mathrm{C} 2, \mathrm{C} 3$, and $\mathrm{C} 4$ mediated significant viral inactivation. Although the above described serum studies provided no evidence for alternative pathway mediation of neutralization, the possible participation of this pathway was also assessed with mixtures of the purified alternative pathway proteins at concentrations equivalent to those found in undiluted serum. Such mixtures of purified proteins at physiologic concentrations are equivalent to serum in alternative pathway functional activities (27). Functional activity of the mixtures used here was verified by showing full activity in lysing rabbit erythrocytes. The PAP was, however, devoid of the ability to neutralize EBV, regardless of the presence or absence of nonimmune $\operatorname{IgG}$ (Table III).

To determine whether completion of the complement sequence was required for neutralization, purified EBV was reacted with C8-depleted nonimmune human serum. C8-depleted serum neutralized EBV as well as untreated serum (Table IV) indicating that the assembled C5b-9 attack complex was not required and therefore lysis was not necessary for neutralization of EBV. These studies showed that EBV was efficiently neutralized by nonimmune human IgG present in normal nonimmune human serum together with the first four reacting classical pathway components $\mathrm{Cl}, \mathrm{C} 2$, 
TABLE IV

EBV Neutralization by C8-depleted Nonimmune Serum

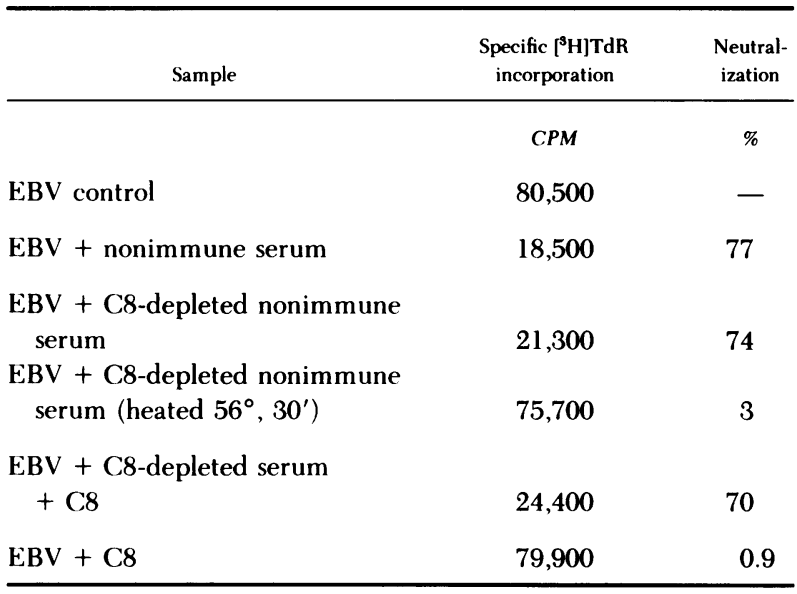

C3, and C4. Neither the alternative pathway nor late acting components were required in this reaction.

Complement deposition on $E B V$. In a further effort to analyze the mechanism of viral neutralization, the interactions of $\mathrm{C} 3$ in nonimmune and immune serum with EBV were examined by rate zonal ultracentrifugal analysis. Labeled EBV was first incubated with normal nonimmune serum, EDTA-treated nonimmune serum, $\mathrm{Mg}^{++}$-EGTA-treated nonimmune serum, or with IgG-depleted immune serum, and subsequently with either buffer or monospecific anti-human C3. The samples were then subjected to dextran density gradient ultracentrifugation. As seen in Fig. $3 \mathrm{~A}$, virus preincubated with nonimmune serum alone sedimented as a single discrete peak in the center of the gradient in agreement with our earlier electron microscopic studies (14). There was no evidence of significant aggregation or viral lysis. In contrast, EBV reacted with nonimmune serum followed by anti-C3 was pelleted to the bottom of the gradient indicating the presence of a $\mathrm{C} 3$ product on the virus envelope (Fig. 3B). Anti-C3 did not pellet virus preincubated with EDTA or $\mathrm{Mg}^{++}$-EGTA-treated nonimmune serum (Fig. 3C, 3D), findings consistent with $\mathrm{C} 3$ (b, bi, or d) deposition exclusively via the classical pathway. IgG was also required for this reaction since virus preincubated with IgG-depleted immune serum was not pelleted by anti-C3 (Fig. 3E). This property was reconstituted by the addition of physiological levels of normal immune IgG to the serum (Fig. 3F).

Analysis of the viral specificity of the IgG antibody in nonimmune serum. Although not previously described, it was considered likely that the IgG in nonimmune sera reactive with EBV represented cross-reacting antibody elicited by other herpesviruses. The most likely candidates were considered to be HSV-1

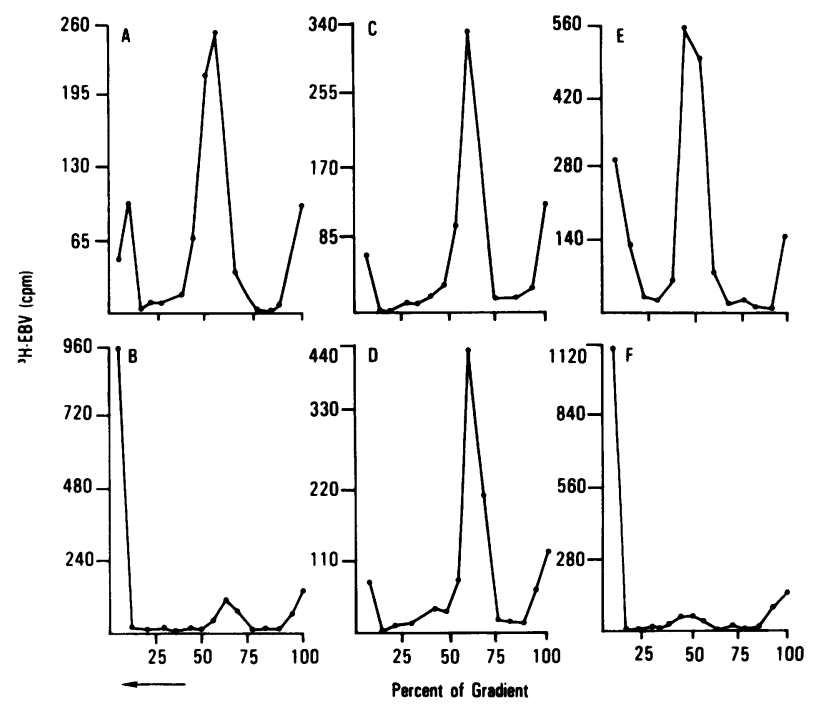

Figure 3 Demonstration of C3 deposition on EBV by nonimmune human serum. Purified ${ }^{3} \mathrm{H}$-labeled EBV was incubated with (A, B) nonimmune serum, (C) nonimmune serum + EDTA, (D) nonimmune serum + $\mathrm{Mg}^{++}$-EGTA, (E) immune serum depleted of IgG, (F) IgG-depleted immune serum reconstituted with IgG. After a second incubation with anti-human C3 except sample (A), which was incubated with buffer, the samples were ultracentrifuged on $5-30 \%$ dextran T-10 gradients. Fractions were then assayed for radioactivity. The direction of sedimentation indicated by the arrow, is to the left.

or CMV. Since three of the four nonimmune sera had moderate to elevated ELISA titers to HSV-1 (data not shown), we first examined the relationship of the antibody to HSV-1. Isolated IgG from normal nonimmune serum ( 1 in Table I) was absorbed with varying amounts of purified EBV, HSV-1, or VSV (as a control). The absorbed IgG was then assayed with purified $\mathrm{Cl}$, C4, C2, and C3 for EBV neutralization (Fig. 4, upper panel) and for binding to EBV in the ELISA (Fig. 4, lower panel). As can be seen, both EBV and HSV-1 absorbed reactivity, but $\mathrm{HSV}-1$ was quantitatively more efficient than EBV in absorbing both the EBVneutralizing and EBV-binding activity of nonimmune IgG. VSV, the control, failed to absorb either reactivity. In other experiments we were unable to absorb the neutralizing and EBV ELISA reactivity of nonimmune serum with equivalent amounts of CMV (data not shown).

Cross-reactivity between IgG antibodies to EBV and HSV-1 in nonimmune sera was also observed in the reciprocal experiment using an HSV-1 ELISA. Purified HSV-l and to a lesser extent EBV, but not CMV absorbed a significant proportion of IgG antibodies reactive with HSV-1 from the nonimmune serum (Fig. 5). 


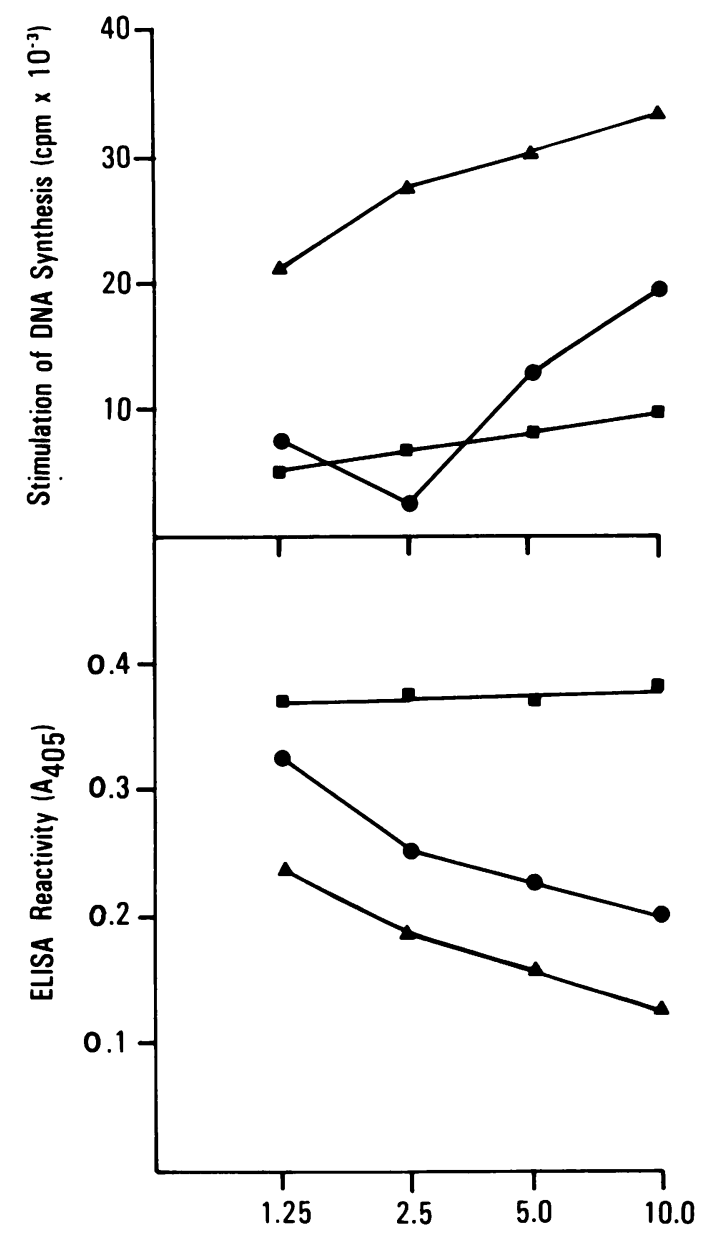

Virus used for Absorption (Virions $\left.\times 10^{6}\right)$

FIGURE 4 Analysis of the viral specificity of the nonimmune IgG reactive with HSV-1 and with EBV. Purified nonimmune IgG $(90 \mu \mathrm{g})$ was preabsorbed with varying amounts $\left(1.25 \times 10^{6}\right.$ to $1 \times 10^{7}$ virions) of isolated $\mathrm{EBV}(-\infty)$, HSV-1 ( $-\Delta)$ or VSV $(\square-\square)$ prior to being assayed undiluted for residual EBV neutralizing activity in the presence of purified $\mathrm{Cl}, \mathrm{C} 4, \mathrm{C} 2$, and C3 (upper panel) or for EBV ELISA reactivity (lower panel).

A serum from a 4-month-old infant (nonimmune 4) lacking detectable reactivity with either EBV or HSV1 (Table V) was examined for ability to neutralize EBV. Since this serum lacked adequate complement function the same agammaglobinemic serum as described in Table I, which lacks neutralizing activity, was added as a complement source. As seen in Table $\mathrm{V}$ this nonimmune serum failed to neutralize EBV in the presence of the agammaglobinemic serum. However, significant neutralization was achieved with the addition of IgG from another nonimmune (1). These findings indicate that both cross-reacting antibody and complement are needed for neutralization of EBV.

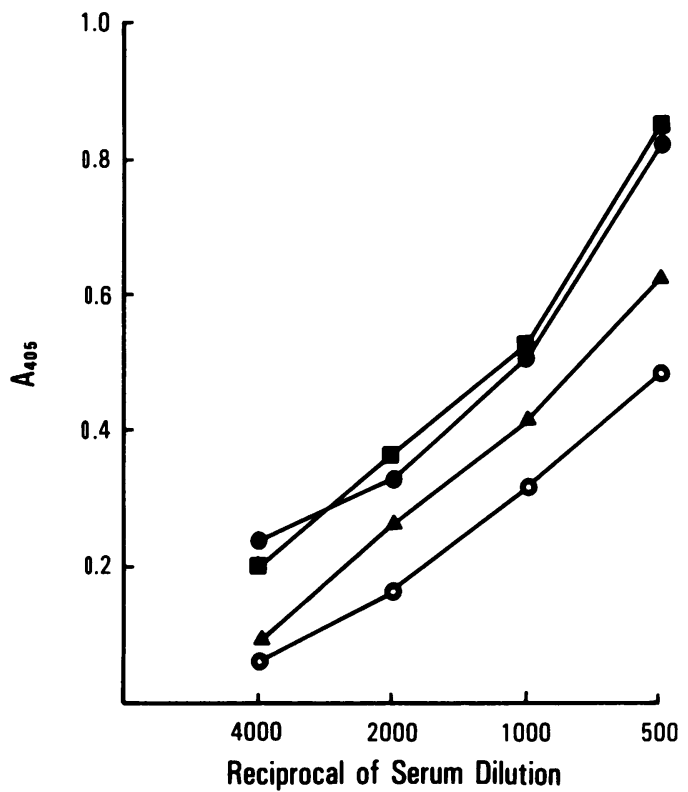

Figure 5 Analysis of the viral specificity of nonimmune IgG reactive with HSV-l in EBV nonimmune serum. Nonimmune serum was preabsorbed with $4 \times 10^{6}$ particles of $\operatorname{CMV}(\bullet), \operatorname{EBV}(\Delta)$, HSV-1 (O), or buffer $(\square)$ after which dilutions of the serum were assayed for residual IgG antibodies reactive with HSV-1 by an ELISA.

The above data together indicate that the primary antigenic reactivity of the nonimmune IgG is with HSV-1.

TABLE V

Immune Reactivity of an EBV and HSV-1 Negative Serum (4)

Serological activity

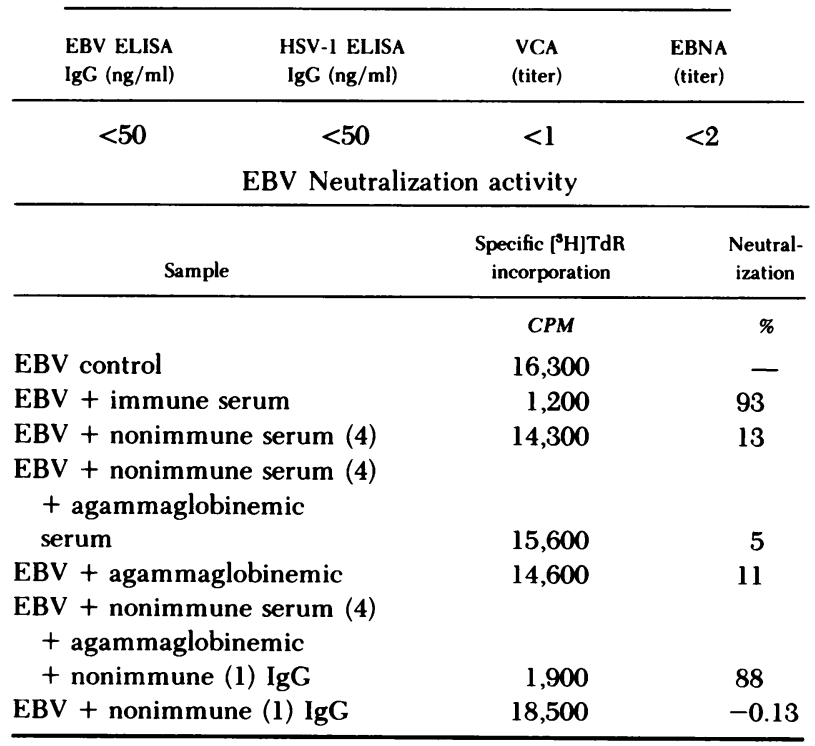




\section{DISCUSSION}

The present studies show that a number of sera lacking VCA and EBNA antibodies to EBV neutralize the virus through the action of complement and a cross-reacting anti-HSV antibody. Two of the nonimmune individuals in the studies presented here were also found to lack specific cytotoxic $\mathrm{T}$ cells reactive with EBV-infected cells (30), thus, further indicating lack of prior exposure to EBV. The IgG antibody present in the normal nonimmune sera is not capable of neutralizing EBV in the absence of complement. This feature clearly distinguishes this antibody from the immune antibody present in $\sim 90 \%$ of the normal U.S. population (normal immune sera) which effectively neutralizes purified EBV in the absence of complement and is not potentiated in this regard by complement (14). Three hypotheses can be offered to explain the failure of the antibody in normal nonimmune human sera to directly neutralize EBV. First, the antibody may not be present in sufficiently high concentrations in the nonimmune sera to directly mediate viral neutralization. In this regard, the EBV ELISA clearly detects less antibody in the nonimmune than in the normal immune sera. Nevertheless, the concentration difference alone is unlikely to explain the failure of normal nonimmune IgG to directly neutralize since normal immune IgG fully neutralizes EBV at a concentration equivalent to a 1:40 dilution of immune serum (14), while the actual antibody concentration difference between normal nonimmune and immune sera, obtained from the ELISA, is only four- or fivefold. Second, the nonimmune antibody could be of low affinity and dissociate from the virus. In all probability, the antibody is of relatively low affinity as it is crossreactive with, rather than elicited by, EBV. However, this property alone is not likely to explain the failure of nonimmune IgG to directly neutralize, since the antibody binds sufficiently firmly to EBV on the ELISA plates to withstand several washes. In contrast, EBV and IgG are incubated together and not washed in the virus-neutralization test. A third possibility, and perhaps the most probable, is that the nonimmune and immune IgG antibody molecules react with different antigenic sites with only the immune antibody being directed to viral surface structures directly involved in attachment to and/or penetration of, cells susceptible to EBV infection.

Although the mechanism by which complement, together with the nonimmune antibody, induces neutralization was not directly addressed in these studies, it is evident that neutralization is not due to complement-dependent lysis, since C8-depleted serum effectively neutralized EBV. Serum lacking C8 does not permit formation of the C5b-9 membrane attack complex required for lysis. Furthermore, the density gra- dient ultracentrifugation studies with ${ }^{3} \mathrm{H}$-labeled EBV and nonimmune serum did not provide evidence of viral disruption. The density gradient studies also showed that complement did not neutralize EBV by inducing viral aggregation, as occurs with some viruses (31). Viral aggregation reduces the net number of infectious particles and thus produces an apparent decrease in viral titer, or neutralization. Complement most likely neutralizes EBV by contributing protein, primarily C3 products, to the virus envelope. Since C3 products are deposited and covalently bind to surfaces in a spatial distribution surrounding each $\mathrm{C}$-activating immune complex, it is likely that some of the C3 fragment molecules become bound to viral structures involved in attachment to and/or penetration of B lymphocytes. This mechanism of complement-dependent viral neutralization has been observed with other viruses and is most likely the mechanism of IgM and complement-mediated inactivation of avian infectious bronchitis virus (32), HSV (33-35), Newcastle disease virus (36), equine arteritis virus (37), vesicular stomatitis virus (38), and vaccinia virus (39). Studies with complement components with some of these viruses show that herpes simplex I (33) and equine arteritis viruses (37) can be neutralized by antibody together with $\mathrm{Cl}$ and $\mathrm{C} 4$ but these viruses and also Newcastle disease virus (36), vesicular stomatitis virus (38), and vaccinia virus (39) are more efficiently neutralized in the presence of C1, C4, C2, and C3. Several viruses have been reported to be neutralized by IgG and complement including the herpesviruses, CMV (40), and equine herpesvirus I (41), however, the complement requirements for these effects remain to be investigated.

It is well documented that lymphoblastoid cells bearing the EBV genome activate the alternative complement pathway (42) and under certain conditions undergo lysis $(43,44)$. The ability to activate the alternative pathway correlates with some evidence of the presence of EBV genome in the cells (42). These observations prompted a thorough investigation of the role of the alternative pathway in EBV neutralization. However, factor D did not restore EBV-neutralizing activity to nonimmune serum depleted of both Clq and factor $\mathrm{D}$ and restoration of the alternative pathway also did not potentiate classical pathway-mediated neutralization. Consistent with these findings, mixtures of the purified alternative pathway proteins at physiologic concentrations failed to neutralize EBV regardless of the presence or absence of nonimmune antibody. Although it remains possible that the virus activates the alternative pathway, such activation, if it occurs, clearly does not result in viral neutralization.

Although the present studies have not conclusively demonstrated that the antibody detected in normal nonimmune sera in the EBV ELISA has the same spec- 
ificity as the $\lg G$ antibody involved in the neutralization reaction, this is probable for the following three reasons. There was a correlation between the two tests with low or high reactivities in the ELISA being reflected in comparable reactivity in the neutralization test. Both the EBV ELISA and neutralizing activities were absorbed with intact EBV (Fig. 4), and therefore the IgG antibody participating in both reactions is directed against viral surface structures. Finally, both reactivities were also absorbed by $\mathrm{HSV}-1$, indicating that the two assays involve an IgG antibody that is cross-reactive with EBV.

The viral antigen reactive with the $\operatorname{IgG}$ antibody in nonimmune human sera and detected in the ELISA and neutralization tests is not the VCA or EBNA antigens associated with EBV, as is evident from the lack of correlation between these reactivities in Table $I$. Since intact Raji and $\mathrm{CBL}^{(\mathrm{EBV}+)}$ cells did not absorb the IgG antibody reactive with EBV (data not shown), this antigen must also differ from the LYDMA antigen (45), a surface antigen involved in $\mathrm{T}$ cell cytotoxicity against EBV-infected cells. Another EBV-associated antigen, the early antigen is not a candidate as it is not present in the virus. It is therefore, most likely that the IgG antibody is directed against one of the EBV envelope antigens such as membrane antigen complex (46).

The specificity of the IgG antibody present in the nonimmune sera that reacted with EBV in the ELISA and, together with $\mathrm{C} 1, \mathrm{C} 4, \mathrm{C} 2$, and $\mathrm{C} 3$, participated in its neutralization, was examined in absorption studies. It was considered most likely that the antibody was elicited by infection with another herpesvirus and cross-reacted with EBV. Absorption studies showed that HSV-1 as well as EBV absorbed the antibody reactive with $\mathrm{EBV}$ in the ELISA and in the neutralization reaction whereas neither $\mathrm{CMV}$, another herpesvirus, nor VSV, as a control, failed to do so (Fig. 4). HSV-1 was quantitatively more efficient than EBV in absorbing the EBV-reactive antibody. The cross-reaction extended also in the reverse direction in that HSV-1 and EBV, but again not CMV, absorbed the antibody reactive with HSV-l as tested in an HSV-1 ELISA (Fig. $5)$. Again, the antibody was more readily absorbed by HSV - 1 than EBV. These studies indicate that the primary specificity of the antibody is almost certainly directed against HSV-1 and that the cross-reaction does not include another human herpesvirus, CMV. The CMV results document the specificity of the absorption studies. Furthermore, since CMV (47) like HSV - 1 (48), has Fc receptors but fails to absorb reactivity, the absorption results cannot be explained by non-specific depletion of immunoglobulin by the $\mathrm{Fc}$ receptors.

EBV and HSV-1, although both herpesviruses, have not been previously reported to elicit cross-reacting antibodies. Among the relatively few reported instances of cross-reactive herpesvirus proteins is the CP1 (gp52) envelope glycoprotein of HSV-1 and HSV-2 (49). Although we do not yet know the extent of crossreactivity of the IgG antibody involved in EBV neutralization with other herpesviruses, we found that CMV did not absorb the IgG antibody reactive with EBV in nonimmune serum. As has been true in the past few years with other families of viruses, it is probable that additional cross-reactions and other evidence of relatedness will become apparent as more sensitive and different assay systems are utilized, such as the ELISA and complement-dependent neutralization reactions used in this study.

In the present studies, fresh undiluted human serum from normal EBV nonimmune individuals neutralized $\sim 10^{7}$ virions of $\mathrm{EBV} / \mathrm{ml}$ of serum. Thus, this complement dependent reaction neutralizes $\mathrm{EBV}$ as well as does immune human serum. Since infectious mononucleosis is known to only develop in individuals lacking antibody (noncomplement requiring) to EBV (50), it is not unlikely that the complement-requiring crossreactive antibody to herpes simplex virus also prevents EBV-induced disease. In this regard, it would be of interest to follow a number of normal nonimmune individuals having EBV cross-reacting antibodies to determine whether they are immune to EBV infection and thus fail to convert to EBV positivity.

\section{ACKNOWLEDGMENTS}

The authors express their gratitude for the samples of umbilical cord blood provided by Virginia Walborn and the maternity staff of Scripps Memorial Hospital. We also thank Emmett Pinney for skillful technical assistance, Roy Johnson for the many helpful discussions on the ELISA. We particularly acknowledge Dr. Robert Schreiber and Dr. Michael Pangburn of this Institute for their generous gifts of the purified alternative pathway proteins, and Nancy Johnson for preparation of the manuscript.

This work is publication 2652 of the Research Institute of Scripps Clinic and was supported in part by National Institutes of Health grants AI 17354 and CA 14692. The generous support of a Leukemia Society of America Fellowship to Dr. Nemerow is also gratefully acknowledged.

\section{REFERENCES}

1. Henle, G., and W. Henle. 1970. Observations on childhood infections with the Epstein-Barr virus. J. Infect. Dis. 121: 303-310.

2. Niederman, J. C., G. Miller, H. A. Pearson, J. S. Pagano, and J. M. Dorvaliby. 1976. Infectious mononucleosis: Epstein-Barr virus shedding in saliva and the oropharynx. N. Engl. J. Med. 294: 1355-1359.

3. Britton, S., M. Andersson-Anvret, P. Gergely, W. Henle, M. Jondal, G. Klein, B. Sandstedt, and E. Svedmyr. 1978. Epstein-Barr virus immunity in a fatal case of infectious mononucleosis. N. Engl. J. Med. 298: 89-92.

4. Purtillo, D. T., L. Hutt, J. Bhowen, J. P. S. Yang, C. Cassel, S. Allegra, and F. S. Rosen. 1978. Immunodefi- 
ciency to the Epstein-Barr virus in the $\mathrm{X}$-linked recessive lymphoproliferative syndrome. Clin. Immunol. Immunopathol. 9: 147-156.

5. Shope, T., D. Dechario, and G. Miller. 1973. Malignant lymphoma in cotton top marmosets after innoculation with Epstein-Barr virus. Proc. Natl. Acad. Sci. USA. 70: 2487-2491.

6. Epstein, M. A., B. G. Achong, and Y. M. Barr. 1964. Virus particles in cultured lymphoblasts from Burkitt's lymphoma. Lancet. I: 702-703.

7. Henle, G., and W. Henle. 1976. Serum IgA antibodies to Epstein-Barr (EBV)-related antigens a new feature of nasopharyngeal carcinoma. Bibl. Haematol. 43: 322325

8. Thorley-Lawson, D. A., L. Chess, and J. L. Strominger. 1977. Suppression of in vitro Epstein-Barr virus infection: A new role for adult human T lymphocytes. J. Exp. Med. 146: 495-508.

9. Shope, T. C., and J. Kaplan. 1979. Inhibition of the in vitro outgrowth of Epstein-Barr virus-infected lymphocytes by $\mathrm{T}_{\mathrm{G}}$ lymphocytes. J. Immunol. 123: 2150-2155.

10. Miller, G., J. C. Niederman, and D. A. Stitt. 1972. Infectious mononucleosis: appearance of neutralizing antibody to Epstein-Barr virus measured by inhibition of formation of lymphoblastoid cell lines. J. Infect. Dis. 125: 403-406.

11. Chisari, F. V., L. K. Curtiss, and F. C. Jensen. 1981. Physiologic concentrations of normal human plasma lipoproteins inhibit the immortilization of peripheral $B$ lymphocytes by the Epstein-Barr virus. J. Clin. Invest. 68: 329-336.

12. Thorley-Lawson, D. A. 1981. The transformation of adult but not newborn human lymphocytes by EpsteinBarr virus and phytohemagglutinin is inhibited by interferon: the early suppression by $\mathrm{T}$ cells of Epstein-Barr infection is mediated by interferon. J. Immunol. 126: 829-833

13. Tischendorf, P., G. J. Schramek, R. C. Balagtas, F. Deinhardt, W. H. Knospe, G. R. Noble, and J. E. Maynard. 1970. Development and persistence of immunity to Epstein-Barr virus in man. J. Infect. Dis. 122: 401-409.

14. Nemerow, G. R., and N. R. Cooper. 1981. Isolation of Epstein-Barr virus and studies of its neutralization by human IgG and complement. J. Immunol. 127: 272-278.

15. Pritchett, R. F., S. D. Haywood, and E. D. Kieff. 1975. DNA of Epstein-Barr virus. I. Comparative studies of the DNA of Epstein-Barr virus from HR-1 and B95-8 cells: Size, structure, and relatedness. J. Virol. 15: 556569 .

16. Jacob, R., and B. Roizman. 1977. Anatomy of herpes simplex virus DNA. VIII. Properties of the replicating DNA. J. Virol. 23: 394-411.

17. Mills, B. J., and N. R. Cooper. 1978. Antibody-independent neutralization by vesicular stomatitis virus by human complement. J. Immunol. 121: 1549-1557.

18. Davidson, W. E., and C. R. Parish. 1975. A procedure for removing red cells and dead cells from lymphoid cell suspension. J. Immunol. Methods. 7: 291-299.

19. Reedman, B. M., and G. Klein. 1973. Cellular localization of an Epstein-Barr virus (EBV)-associated complement-fixing antigen producer and nonproducer lymphoblastoid cell lines. Int. J. Cancer. 11: 499-520.

20. Tenner, A. J., P. H. Lesavre, and N. R. Cooper. 1981. Purification and radiolabeling of human Clq. J. Immunol. 127: 648-653.

21. Ziccardi, R. J., and N. R. Cooper. 1976. Physiochemical and functional characterization of the $\mathrm{Clr}$ subunit of the first complement component. J. Immunol. 116: 496-503.
22. Valet, G., and N. R. Cooper. 1974. Isolation and characterization of the proenzyme form of the Cls subunit of the first complement component. J. Immunol. 112: 339-350.

23. Schreiber, R. D., and H. J. Muller-Eberhard. 1974. Fourth component of human complement: Description of a three polypeptide chain structure. J. Exp. Med. 140: 1324-1335.

24. Cooper, N. R., M. J. Polley, and H. J. Muller-Eberhard. 1970. The second component of human complement (C2): quantitative molecular analysis of its reactions in immune hemolysis. Immunochemistry. 7: 341-356.

25. Tack, B. J., and J. W. Prahl. 1976. Third component of human complement: Purification from plasma and physiochemical characterization. Biochemistry. 15: 45134521

26. Reboul, A., G. J. Arlaud, R. B. Sim, and M. G. Colomb. 1977. A simplified procedure for the purification of C1Inactivator from human plasma. Interaction with complement subcomponents Clr and Cls. FEBS (Fed. Eur. Biochem. Soc.) Lett. 79: 45-50.

27. Schreiber, R. D., M. K. Pangburn, P. H. Lesavre, and H. J. Muller-Eberhard. 1978. Initiation of the alternative pathway of complement: Recognition of activators by bound C3b and assembly of the entire pathway from six isolated proteins. Proc. Natl. Acad. Sci. USA. 75: 39483952.

28. Vestergaard, B. F., J. Heese,B. Norrild, and G. Klein. 1978. Production of rabbit antibodies against the viral capsid antigen (VCA) of the Epstein-Barr virus (EBV). Int. J. Cancer. 21: 323-328.

29. Robinson, J., and G. Miller. 1975. Assay for Epstein-Barr virus based on stimulation of DNA synthesis in mixed leukocytes from human umbilical cord blood. J. Virol. 15: 1065-1072.

30. Tsoukas, C. D., R. I. Fox, S. F. Slovin, D. A. Carson, M. Pellegrino, S. Fong, J. L. Pasquali, S. Ferrone, P. Kung, and J. H. Vaughn. 1981. T lymphocyte-mediated cytotoxicity against autologous EBV-genome-bearing B cells. J. Immunol. 126: 1742-1746.

31. Oldstone, M. B. A., N. R. Cooper, and D. L. Larson. 1974. Formation and biologic role of polyoma virus-antibody complexes. J. Exp. Med. 140: 549-565.

32. Berry, D. M., and J. D. Almeida. 1968. The morphological and biological effects of various antisera on avian infectious bronchitis virus. J. Gen. Virol. 3: 97-102.

33. Daniels, C. A., T. Borsos, H. J. Rapp, R. Snyderman, and A. L. Notkins. 1969. Neutralization of sensitized virus by the fourth component of complement. Science (Wash. D. C.). 165: 508-509.

34. Daniels, C. A., T. Borsos, H. J. Rapp, R. Snyderman, and A. L. Notkins. 1970. Neutralization of sensitized virus by purified components of complement. Proc. Natl. Acad. USA. 65: 528-535.

35. Notkins, A. L., J. Rosenthal, and B. Johnson. 1971. Ratezonal centrifugation of herpes simplex virus-antibody complexes. Virology. 43: 321-325.

36. Linscott, W. D., and W. E. Levinson. 1969. Complement components required for virus neutralization by early immunoglobulin antibody. Proc. Natl. Acad. Sci. USA. 64: 520-527.

37. Radwan, A. I., and T. B. Crawford. 1974. The mechanisms of neutralization of sensitized equine arteritis virus by complement components. J. Gen. Virol. 25: 229-237.

38. Beebe, D. P., and N. R. Cooper. 1981. Neutralization of vesicular stomatitis virus (VSV) by human complement requires a natural IgM antibody present in human serum. J. Immunol. 126: 1562-1568. 
39. Leddy, J. P., R. L. Simons, and R. G. Douglas. 1977. Effect of selective complement deficiency on the rate of neutralization of enveloped viruses by human sera. J. Immunol. 118: 28-34.

40. Graham, B. J., Y. Minamishima, G. R. Dreesman, H. G. Naines, and M. Benyesh-Melnick. 1971. Complementrequiring neutralizing antibodies in hyperimmune sera to human cytomegaloviruses. J. Immunol. 107: 16181630.

41. Snyder, D. B., A. C. Myrup, and S. K. Dutta. 1981. Complement requirement for virus neutralization by antibody and reduced serum complement levels associated with experimental equine herpesvirus I infection. Infect. Immun. 31: 636-640.

42. McConnell, I., G. Klein, T. F. Lint, and P. J. Lachman. 1978. Activation of the alternative complement pathway by human B lymphoma lines is associated with EpsteinBarr virus transformation of the cells. Eur. J. Immunol. 8: 453-458.

43. Baker, P. J., T. F. Lint, R. F. Mortensen, and H. Gewurz. 1977. C567-initiated cytolysis of lymphoid cells: Description of the phenomenon and studies on its control by C567-inhibitors. J. Immunol. 118: 198-202.

44. Schreiber, R. D., M. K. Pangburn, R. G. Medicus, and H. J. Muller-Eberhard. 1980. Raji cell injury and subsequent lysis by the purified cytolytic alternative path- way of human complement. Clin. Immunol. Immunopathol. 15: 384-396.

45. Svedmyr, E., and M. Jondal. 1975. Cytotoxic cells specific for B cell lines transformed by Epstein-Barr virus are present in patients with infectious mononucleosis. Proc. Natl. Acad. Sci. USA. 72: 1622-1626.

46. Thorley-Lawson, D. A. 1979. Characterization of crossreacting antigens on the Epstein-Barr virus envelope and plasma membranes of producer cells. Cell. 16: 33-42.

47. Westermoreland, D., S. St. Jeor, and F. Rapp. 1976. The development by cytomegalovirus-infected cells of binding affinity for normal human immunoglobulin. J. Immunol. 116: 1566-1570.

48. Para, M. F., R. B. Banke, and P. G. Spear. 1982. Glycoprotein $\mathrm{gE}$ of Herpes simplex virus type 1: Effects of anti-gE virion infectivity and on virus-induced $\mathrm{F}_{\mathrm{C}}$-binding receptors. J. Virol. 41: 129-136.

49. Cohen, G. H., M. Katze, C. Hydrean-Stern, and R. J. Eisenberg. 1978. Type common CP-1 antigen of herpes simplex virus is associated with a 59,000 molecular weight envelope glycoprotein. J. Virol. 27: 172-181.

50. Hewetson, J. F., G. Rocchi, W. Henle, and G. Henle. 1973. Neutralizing antibodies to Epstein-Barr virus in healthy populations and patients with infectious mononucleosis. J. Infect. Dis. 128: 283-289. 